\title{
The Economic Value of Environmental Capital Inputs Used to Produce the Gross Domestic Product in Ghana, 1993 to 2012
}

\author{
Kwabena Asomanin Anaman ${ }^{1} \&$ Felix Agyei-Sasu ${ }^{1}$ \\ ${ }^{1}$ Division of Economics, Institute of Statistical, Social and Economic Research, University of Ghana, Legon, Accra, \\ Ghana \\ Correspondence: Kwabena Asomanin Anaman, Professor, Division of Economics, Institute of Statistical, Social and \\ Economic Research, University of Ghana, Legon, Accra, Ghana. E-mail: kwabenaasomanin@hotmail.com
}

Received: June 26, 2014

Accepted: July 21, 2014

Online Published: July 31, 2014

doi:10.5430/rwe.v5n2p74

URL: http://dx.doi.org/10.5430/rwe.v5n2p74

\begin{abstract}
Ghana has been one of the fastest growing countries in the world over the last decade driven by exports of oil from newly-discovered offshore oil fields, the export of its traditional commodities of cocoa, gold and other extractive minerals, construction, and the expansion of services related to banking, information and communication technologies, and tourism. Measured by the change in real gross domestic product (GDP), the economy grew at a pace of $7.5 \%$ over the period from 2004 to 2013 and 8.6\% from 2009 to 2013, and was among the top 15 performers in the world. The Ghanaian economy was formally classified as lower-middle-income in 2010 with a per capita income of over 1,300 United States dollars. Our study focuses on measuring the values of labour and capital inputs used to produce the goods and services incorporated in the GDP. We acknowledge the existence of two types of capital inputs used to produce final goods and services. These are (1) human-made or manufactured capital such as machinery and equipment and (2) environmental capital items such as proven oil and gas reserves, mineral deposits, forest and water resources that are required to produce final goods and services in the economy. We estimated the size of environmental or natural capital stock used to produce the GDP over the twenty-year period, 1993 to 2012 assuming that the economy as a whole exhibited a constant returns to scale feature. The results indicate that over the period, 1993 to 2012, the average share attributed to labour in the production of GDP was about $45 \%$. Human-made capital inputs contributed on average about $19 \%$ of GDP. The remaining share of $36 \%$ was the estimated value of environmental capital inputs used to produce GDP. We also established that the aggregate environmental depreciation was significantly related to GDP in a positive log-linear fashion while its relationship to real interest rate was negative but not statistically significant.
\end{abstract}

Keywords: environmental accounting, environmental depreciation, environmental macroeconomics, GDP accounting, Ghana, national income accounting, natural capital

\section{Introduction and Problem Statement}

\subsection{Background}

Ghana lies between latitude 11.50 North and 4.50 South and longitude 3.50 West and 1.30 East. It has a land area of $239,460 \mathrm{~km}^{2}$ and an estimated current population of 26 million (June 2014 estimate) based on projections from the 2010 Population and Housing Census conducted by the Ghana Statistical Service (GSS). The modern Ghanaian economic history traces back to 8th February 1951 when an elected local government was established in unison with British colonial rule. Political independence was achieved on 6 March 1957 when the country became the first Sub-Saharan African country to become independent after 113 years of British colonial rule from 1844. From 1951 to the end of the First Republic in February 1966, the country witnessed considerable socio-economic transformation based on moderate economic growth, the establishment of numerous primary, secondary schools and universities. The Akosombo hydro-electric dam linked to the largest man-made lake, the Volta Lake, was completed in 1965 and was inaugurated in January 1966. The socio-economic transformation of Ghana over the 15-year period (1951 to 1966) was achieved largely on the back of revenues from the export of cocoa for which Ghana was the largest producer from the early 1940s to about 1978. The country is currently the second largest producer of the commodity after La Cote D'Ivoire, Ghana's western neighbour.

Based on the estimates from the data base of International Financial Statistics Yearbook issues from 1989 to 2005, Ghana in 1960 had a per capita GDP of 198.6 United states dollars (US\$) and was higher than the US\$151.4 for South Korea. The collapse of world cocoa prices in 1964/1965, the severe drought of 1962 were two major external events that adversely affected the economy during the first nine years of political independence (Anaman and 
Osei-Amponsah, 2007). Ghana accounted for about $37.5 \%$ of the world supply of cocoa in $1964 / 65$ and the very low prices during that year led to a short-term balance of payments crisis. The overthrow of the civilian government in February 1966 led to a 27-year period of political instability until the restoration of constitutional civilian rule in January 1993. Since 1993 the country has witnessed a 21-year period of continuous political stability with two peaceful changes in government after national elections in 2000 and 2008 under democratic dispensation. Anaman (2006) showed that political stability was one of the key drivers of economic growth of Ghana from 1966 to 2000.

A major environmental feature of this 27-year period of political instability (1966 to 1993) was the extremely-severe droughts that occurred in 1977 and 1982/1983 which led to inflation rates of over 100\% in those years. These droughts are now known to have been linked to an extreme form of the El Nino Southern Oscillation (ENSO) weather phenomenon. Modest ENSO phenomena also occurred in 1998/99 and 2005/2006 and led to reduced growth due to reduced energy from hydropower sources. Hydro-powered electricity largely based on the Akosombo dam has remained the biggest source of electricity energy in the country since January 1966.

Ghana has been one of the fastest growing countries in the world over the last decade driven by exports of oil from newly-discovered oil fields starting in January 2011, the export of its traditional commodities of cocoa, gold and other minerals, construction, tourism and the expansion of services related to banking, information and communication technologies. Measured by the change in real GDP, the economy grew at an average pace of $5.9 \%$ annually from 1993 to 2012; this annual economic growth averaged $7.6 \%$ over the more recent decade from 2004 to 2013 , and $8.6 \%$ over the five-year period, 2009 to 2013, making the country one of the top 15 growth performers in the world over the last five years. The Ghanaian economy was formally classified as lower-middle-income in 2010 with a per capita income of over 1,300 United States dollars (Ghana Statistical Service, 2010).

It is clear from the overview and introduction of the topic that the steady growth of the economy of Ghana has been largely dependent on political stability and the development and exploitation of natural resources including primary and agricultural products which are largely exported to the rest of the world. Given the continuous political stability of the country since 1993, the issue of attribution of the causes of growth of Ghana in the more recent era has shifted to a search for other causes and sources of growth beyond political stability. Yet as indicated earlier, disturbances and shocks emanating from the natural environment such as droughts have had considerable effect on economic growth when they have occurred. Further, given that exports derived from natural resources such as cocoa, gold and other minerals and more recently oil have been the bedrock of accumulation of the human-produced wealth of the country, it is useful to establish the impact of the level of environmental capital inputs on the production of final goods and services of the economy which are normally incorporated in the GDP. This background sets the scene for more detailed explanation of the statement of the problem underlying this study which is given below.

\subsection{Problem Statement}

GDP is defined as the value of the final goods and services produced in an economy within a country's internationally-recognised borders normally over a period of one year. The concept of GDP has been used by many nations since the 1950s to gauge the performance of their economies and as estimate of economic welfare or material happiness of members of society. A related concept, the net domestic product (NDP), is defined as GDP less the depreciation of the aggregate human-made capital stock used to produce GDP such as machinery and equipment. However, the welfare of human beings in any society depends importantly on the access and use of many non-market goods and services. Since GDP and NDP measure essentially market-based goods and services, it neglects many goods and services which are important for the achievement of material happiness of societies. The criticism of GDP through its neglect of non-market goods and services has been partly ameliorated through the inclusion of several non-market goods and services in its estimation, for example, subsistence food production, and both market-based traditional and modern government services.

Despite this enhancement of GDP through the inclusion of several non-market goods and services, the use of GDP as a measure of social welfare and economic growth has often been criticised by many environmental economists because it does not consider the destruction of the natural environment that is often associated with economic growth. A related criticism of the use GDP to measure economic welfare is that expenditures incurred in maintaining the status of the environment are included in GDP rather than being subtracted from it (Pearce and Barbier, 2000; Common and Stagl, 2005). It is worth noting that for a nation to assess the sustainability of her economic growth and development, the scope and coverage of economic accounting ought to be broadened to include the use of non-marketed natural assets and losses in income-generation resulting from the depletion and degradation of natural capital (United Nations, 2000, 2012). These are not fully accounted for in the conventional national income accounts.

The natural environment provides valuable materials for the production of goods and services and also acts as a sink for the disposal and management of the wastes from economic processes. The natural environment acts as a source for the release of oxygen for breathing and human survival and also absorbs carbon dioxide which reduces excessive warming of the earth's atmosphere. The natural environment, such as the oceans, also absorbs greenhouse gases. The 
generally under-priced or un-priced nature of environmental resources has resulted in their misuse and abuse leading to widespread environmental degradation around the world. Increasing awareness of environmental degradation and activism by environmentalists, including many traditional chiefs and traditional religious priests, in different parts of the world have led to efforts to modify national income measures such as GDP and NDP to incorporate the services of the natural environment and to consider the impacts of economic growth on the natural environment. National income accounts modified to include deterioration of the natural environment are often called environmentally-adjusted domestic product (EDP). These EDP accounts often do not replace GDP and NDP but are used more as satellite or supplementary accounts (Thampapillai, 2002).

Since the natural environment is required to produce many goods and services, it can be regarded as capital stock similar to human-made capital such as buildings and machinery (Thampapillai and Uhlin, 1997). The terms "natural capital" and "environmental capital" have been coined by environmental economists to describe the important role of the natural environment as a durable asset that generates flows of goods and services. There has been increasing level of effort to incorporate both environmental capital and human-made capital in the national income accounting system. The measurement of environmental capital in national income accounting systems has been undertaken for several developing countries. Examples include the works of Mohammed and Anaman (2003) for Brunei Darussalam, Bartelmus et al. (1992) for Papua New Guinea and Solorzano et al. (1991) for Costa Rica.

Ghana's real economy or the real sector is categorised into three main sectors: agriculture, industry and services by the Ghana Statistical Service. Given Ghana's new status as an oil exporter since January 2011 and its traditional dependence on other non-renewable natural resource such as gold and diamonds, the incorporation of environmental capital in national income accounting of Ghana is important as means of estimating sustainable national income and providing information on policies needed to ensure the attainment of a properly-diversified economy. Again, it is important that newly-discovered offshore deposits being mined for exports since the beginning of 2011 are saved and invested in productive investments that ensure increasing levels of total environmental capital stock and sustainable national income.

In order to achieve this goal, it is important to estimate the level of environmental capital stock and the amount of this stock that is actually used to produce the GDP of Ghana. Further, economic growth that destroys the environment at a fast pace may bring the whole economy into a steep decline in the future given that the level of total environmental capital can be a limiting constraint to the production of material goods and services. For example, if through massive destruction of the environment, the environment ceases to be an important sink to absorb the pollution from the production of goods and services, economic growth can decline sharply.

It is important that as the economy grows, some of the revenues generated from growth are set aside to replace the proportion of total environmental capital stock used in the production of GDP. Setting aside revenues from economic growth for future uses may be useful. But we contend that it is important to judiciously replace environmental capital that is destroyed through economic growth so that future generations are given high levels of total environmental capital stock that allow them to produce a sustainable level of income. For instance, some of the money generated currently from the exploitation of oil reserves in Ghana can be used to create new national parks and repair major natural assets that have been impaired by economic growth. If this is done, it will increase total environmental capital stock and in the process boost growth in tourism industry and create many labour-intensive employment opportunities.

The discovery of oil in commercial quantities in Ghana since 2007 and the start of actual production and export of oil in commercial quantities since 2011, has led to the establishment of funds for the financing of projects and also for the saving of some of the funds from the oil production for future projects. These funds are the Stabilization and Heritage Funds established by the Parliament of Ghana in 2010. However, there are no funds set aside specifically to cater for environmental investment that deals with the depreciation of the natural environment and ensures that the total natural and environmental capital stock of Ghana is increased and not reduced in both quantity and quality.

We contend that the amount of the oil revenue or percentage allocated to the various funds should be related to the level of the environmental capital stock used in the production of GDP including oil and mining activities. This would provide the amount that could be invested in replenishing the environmental capital stock. Estimating the environmental capital stock could determine how much of the oil revenue should be invested in the various funds in order to replenish the environmental capital stock. Areas/sectors that need investment include reviving dead river bodies and ecosytems, afforestation and development of national parks to ensure growth of environmental capital stock, and not only human-made capital stock.

The lack of studies on the measurement and analysis of environmental or natural capital with regards to the economy of Ghana makes it imperative that research work be undertaken to estimate environmental capital for the country. The rest of this paper is organised as follows: the objectives of the study are described in the next section. This is 
followed by the reporting of a summary of the literature reviewed. The third section of this report is devoted to the methodology used for the study. The results, conclusions and policy implications follow.

\subsection{Objectives of the Study}

The main goal of this study is to estimate the total environmental capital stock of Ghana and the amount of environmental capital resources used to produce GDP based on the rebased national accounts that were introduced in 2010. Specifically, the objectives of the study are as follows:

1). To estimate the size of the total environmental capital stock of Ghana for the period, 1993 to 2012, based on rebased GDP figures derived by the Ghana Statistical Service (GSS).

2). To ascertain the amount of environmental capital inputs used in the production of GDP in Ghana from 1993 to 2012 based on the rebased GDP figures derived by GSS.

3). To analyse the factors influencing the level of depreciation allowance for environmental capital inputs in Ghana based on available data from 1993 to 2011.

\section{Literature Review}

\subsection{The Essence of Natural Environment as Capital for Economic Growth}

The natural environment is a critical component of every economy as it serves as a resource provider and waste receiver to sustain productivity. Whereas the environment often serves as the basic source of raw materials for economic development, the processes of economic expansion impacts the environment directly or indirectly. The backward and forward linkages have generated debates between environmental conservationists and development activists over the years. Different models and theories of economics have long recognised the critical role of environmental sustainability to economic sustainability. The two main economic thoughts, the classical and the neoclassical theories, recognise the essence of the natural environment's contribution to economic growth and development. Classical economic theories assume constraints related to environmental limits and neoclassical economic theories acknowledge the natural environment in its premise. Classical economics have however been associated more with the natural environment than neoclassical economics. As explained by Thampapillai (2002), from the period from 1945 to 1980, mainstream neoclassical economists dwelt excessively on economic growth with the assumption that output was determined primarily by labour and human-made capital thus neglecting the important roles of the environment.

The Brundtland Commission (1987) provided a major impetus for the more extensive recognition of the environment in economic growth and national income accounting studies emphasing that environment and development are not separate challenges but are intertwined. The role of the environment as the essential platform for economic activities became a maxim among economists and governments after the publication of the Bruntland Commission Report in 1987. A circular flow of cause and effect relationship between poverty and environmental damage is inevitable for countries that are not able to adequately sustain their environments. Environmental degradation causes poverty while poverty often leads to excessive environmental degradation as a result of over exploitation and neglect of the environment.

\subsection{Brief Historical Perspective of National Income Accounting and Its Environmental Linkage}

As far back as the $17^{\text {th }}$ century (1798), Thomas Malthus observed that the human population was growing faster than food supply and predicted that it would lead to overpopulation, war, famine and social upheavals in the near future if the rate of population growth was unchecked. This gave an indication that economic expansion could be limited by the capacity of the environmental system to provide adequate support in terms of shelter, health and wealth. The main thrust of Malthus proposition was food security and he suggested that the eco-scarcity argument should be incorporated in national development policies.

Ricardo (1817) extended the environmental constraint argument of Malthus further with the concept of diminishing marginal returns using land as a resource. According to Ricardo, given a fixed piece or size of land, as more and more labour are employed on that unit of land, there will be diminishing marginal returns per additional labour employed. In this case the fixity of land places a natural check on labour productivity, wealth creation and welfare, and population growth. As fertile land becomes scarce, economic growth and population expansion decline. Hotelling (1931) developed the principle of user cost which was related to the cost of the resource to future generations resulting from the use of the resource by the current generation. This concept served as an important tool to rationalise the exploitation of natural resources, curb overexploitation and preserve the resource for use by future generations.

Hartwick (1977) illustrated the importance of the environment in economic development by suggesting that rents from the extraction of exhaustible natural resources should be re-invested into reproducible capital so that both the current and future generations would benefit. The natural environment is considered as a capital that earns interest 
when saved and can be used up over time just as human-made capital. There is the need to impute the cost of depreciation for natural environmental resources used for economic growth in national income accounts. Subsequently, after the seminal work of Hartwick, there have been attempts to modify existing national income accounting systems to capture the contributions of the natural environment.

Solow (1993) made a case for the full capture of the contribution of the natural environment to national income by adopting environmentally-adjusted national accounts. This environmentally-adjusted Net Domestic Product (NDP) provides a true picture of whether a country is on the right path of sustainable development. This is because the environmentally-adjusted NDP reflects the depletion of natural resources and decline in the quality of environment as a result of production. Solow's argument is compatible with the point made by Hicks (1946) who suggests that the income of a country is the maximum amount which can be consumed in a given period but does not compromise future consumption by reducing the capital stock. Following these contributions, environmental considerations have been incorporated into conventional macroeconomic models and concepts for policy making and implementation (Thampapillai, 2002).

The environment as the platform for economic activities has been suggested by many thinkers (Bloom and Sachs, 1998; Masters and McMillan, 2001; Armstrong and Read, 2004). Human-made interventions through policy and market failures have been highlighted by environmental economists to have serious repercussion on the environment. Policy failures manifest themselves in the form of inadequate property rights regimes, under-pricing of natural resources, subsidies on energy, fertilizers and pesticides. Market failures emanate from the existence of economic activities that imposes cost on other economic agents (Hamilton and Lutz, 1996).

Environmental economists have questioned the economic indicators used for policy formulation and real economic growth. This is as a result of lack of accounting for the use of the environment in the total wealth of the goods and services produced by a country as. The national income valuation ideally is expected to border on the value of goods and services that is consumed in a nation during a given period without reducing future consumption opportunities (Lindhal, 1933). In effect the environmental resources we use today to generate economic activities must be available for future generation and hence the need to cater for environmental investment and depreciation for real national income valuation and economic growth.

The methods of environmental accounting and measure of sustainable growth should hinge on adequate valuation of environmental capital stock. There have been several approaches which have been used to quantify the magnitude and value of natural capital assets. One of such method is the geographic information systems (GIS) which include remote sensing and environmental audits. Considering the time constraints in order to arrive at fine-tuned measurement approach and valuations, the search and use of proxies become inevitable. A proxy approach using the Cobb-Douglas (C-D) production function has been widely used in the valuation of environmental capital stock. The function includes environmental capital stock as a principal argument variable alongside labour and human-made or manufactured capital (Thampapillai, 2002).

The over-estimation of the national income of nations as a result of lack accounting for environmental depreciation is well known. The advocacy for the inclusion of the environment in national accounting by environmentalists and researchers, led to the exploration of the environmental factor in economic studies. For example, Thampapillai and Uhlin (1997) constructed a Keynesian framework for the determination of sustainable income for the United States over a 37-year period (1950-1986) using a linear and non-linear income determination approaches. Their results proved efficiency improvement of the utilisation of environmental capital and possible convergence between sustainable and actual income paths. A study by Thampapillai and Hanf (2000) used a cobb-douglas production function containing environmental capital following Solow (1986) conceptual exposition. They indicated that, when sustainability and the non-sustainability of at least some components of environmental capital are recognised, it is possible to show that all rents owing to the entire stock of environmental capital need to be set aside as a depreciation allowance.

There has been increased impetus in the last 30 years to move from a conceptual framework of environmental and natural capital to put numbers around the concept and incorporate these numbers in the measurement of a nation's wealth. World Bank (2012) indicates that natural or environmental capital makes up about $36 \%$ of the wealth of developing countries. Internationally-agreed methods for valuing natural resources like minerals, timber and fisheries are now available with the adoption of the United Nations Statistical Commission of the System for the Environmental and Economic Accounts in 2012. More work is needed to standardise methods for valuing more complex environmental services such as non-traded and non-marketed ecosystem services and traditional religious services related to the conservation of natural resources around the world.

\subsection{Brief Discussion of the Environmental Resource Profile of Ghana}

\section{Land Resource}

Ghana lies in the equatorial climatic region and has a total land area of $239,460 \mathrm{~km}^{2}$ and $8,520 \mathrm{~km}^{2}$ of water resource. Land in Ghana is either used for agricultural purpose or non-agricultural purpose. Forestry, wildlife, mining, 
settlements, industrial estate development, military and defense, transport networks are some few examples of non-agricultural land uses in Ghana. In 2011, 66.6\% of lands were estimated to be under agricultural land use compared with the total land area of Ghana. The remaining was spread between other land uses as shown in Table 1 (FAOSTAT, 2013). It is reflected here that agriculture, which is dominated by small holders is an important economic activity for most Ghanaians as per its dominance of land use.

Table 1. Land area and land use in Ghana

\begin{tabular}{lrrr}
\hline Land Area in 100Ha & $\mathbf{2 0 0 9}$ & $\mathbf{2 0 1 0}$ & $\mathbf{2 0 1 1}$ \\
\hline Country area (100Ha) & $\mathbf{2 3 8 5 4}$ & $\mathbf{2 3 8 5 4}$ & $\mathbf{2 3 8 5 4}$ \\
\hline Land area & 22754 & 22754 & 22754 \\
\hline (\% of total country area) & $(95.39)$ & $(95.39)$ & $(95.39)$ \\
\hline Agricultural area & 15750 & 15800 & 15900 \\
\hline (\% of total country area) & $(66.03)$ & $(66.24)$ & $(66.66)$ \\
\hline Forest area & 5055.4 & 4940 & 4824.6 \\
\hline (\% of total country area) & $(21.19)$ & $(20.71)$ & $(20.23)$ \\
\hline Other land & 1948.6 & 2014 & 2029.4 \\
\hline (\% of total country area) & $(8.17)$ & $(8.44)$ & $(8.51)$ \\
\hline
\end{tabular}

Source: FAOSTAT, 2013

\section{Rainfall}

Rainfall and rain water are key to Ghana's agricultural development. This is because agriculture which is linked to the predominant land use is largely rain fed. Ghana's rainfall patterns are linked to two major air masses: the dry and warm north-easterly trade winds and the moist south-westerly or the monsoons winds. The moist maritime monsoons are associated with rainfall while the dry north-eastern trade winds are associated with dry and dusty conditions. Thus, the country has distinct dry and wet seasons. The moist south-westerly or the monsoons usually start from the month of March through to November and even in December sometimes while the north-eastern trade winds appear from December to February (Euronet Consulting, 2012).

Rainfall pattern in Ghana is such that it generally decreases from the south to the north. The southwest extreme end of the country which records over $2,000 \mathrm{~mm}$ per annum of rainfall is the wettest zone while the extreme north has a record of annual rainfall often less than $1,000 \mathrm{~mm}$.

The south-eastern coastal tip is the driest area in the country in terms of rainfall with about $750 \mathrm{~mm}$ recorded annually (Dickson and Benneh, 1988; Benneh et al., 1990). Southern Ghana enjoys two distinct cropping seasons; the major and minor season due to the movement of the southwestern monsoon winds by March and the late arrival of the northeastern trade. In contrast, Northern Ghana's shorter duration of rainfall makes the zone experience only one planting season. However, due to climate variability, the occurrences and intensity of these winds have been erratic which sometimes makes it difficult for even southern Ghana to experience two complete planting seasons. This feature might be linked to the ENSO weather phenomenon.

Forest and Vegetation

The two main types of natural forests in Ghana are the closed forest and savannah forest. The closed forests can be found in the Ashanti, Eastern, Western, Brong-Ahafo, Volta and Central Regions of Ghana. The closed natural forest type comprises the wet evergreen forest, moist evergreen forest, moist semi-deciduous forest, and dry semi-deciduous forest. The Savannah forest which is found in the three Northern regions, Greater Accra Region and some parts Eastern, Central and Volta Regions, is composed of the Interior Savannah (Guinea Savannah), North-east Savannah (Sudan Savannah) and Coastal Savannah (Figure 1) (Ministry of Land and Natural Resources (MLNR), 2012). There are about 266 protected forest areas for which the majority host the country's forest reserves and national parks. The protected areas cover 25,559 sq. km, of which 16,788 sq. km are in the high forest zone (HFZ). There is a rich biodiversity in Ghana's HFZ and it falls within the West African Biodiversity Hotspot (Ministry of Land and Natural Resources (MLNR), 2012).

Available data over the years show that, Ghana has been gradually been losing her hard wood forest cover. Ghana's total forest cover, which stood at 8.2 million hectares (i.e., $34 \%$ of the total land area) at the turn of the last century, is now less than 1.6 million hectares and has suffered from an estimated annual deforestation rate of $2.0 \%$ (Ministry of 
Lands and Natural Resource (MLNR), 2012). This has been due to anthropogenic activities such as population growth, logging, farming, bush fires and illegal artisanal small scale mining (often called galamsey) (see Figure 2 for trend of forested area in Ghana). There have been some government intervention programmes to reduce deforestation such as the National Afforestation Programme and the formulation of the National Forest Investment Policy; however these programmes have generally been inadequate to deal effectively with the intensity of deforestation.

\section{Minerals}

Ghana has a wide range of mineral resources which includes gold, manganese, bauxite, diamond, and silver. There are also unexploited economic deposits of iron ore, limestone, kaolin, feldspar, and silica sand (www.ghana-mining.org). There has been discovery of large deposits of copper, phosphate, nickel, chromium and uranium. The expected production of several of these newly-discovered mineral deposits could significantly raise national income but would also contribute considerably to environmental degradation including reducing the quality of rivers. This concern prompts our current study to allow policymakers to understand the level of environmental capital used to produce GDP and reinforce the message that the reduction of environmental capital stock needs to be replenished by continuous societal investments in natural resources.

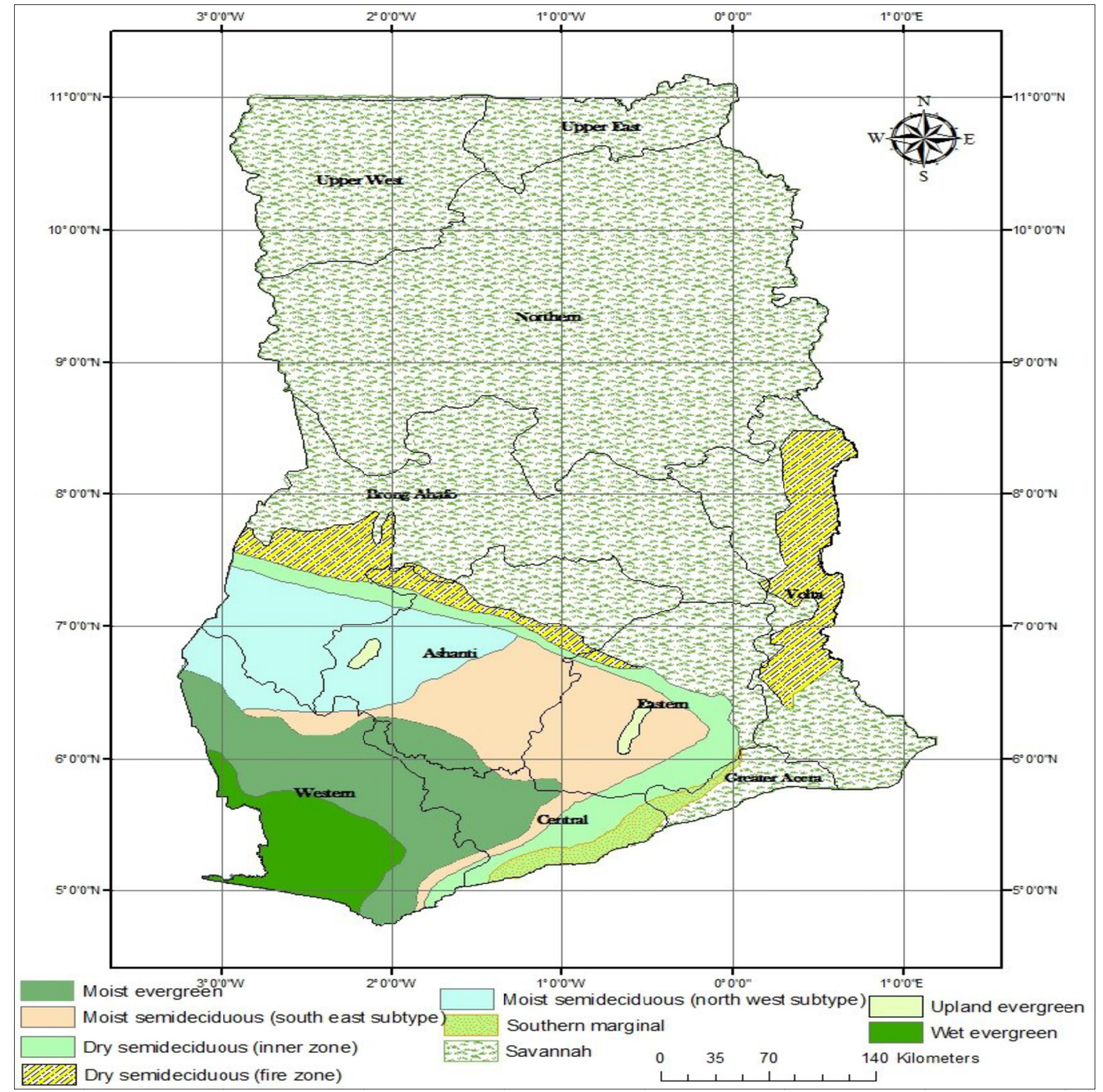

Figure 1. Ghana's vegetation map

Source: Adapted from Ghana Forest Investment Plan (Ministry of Land and Natural Resources), 2012. 


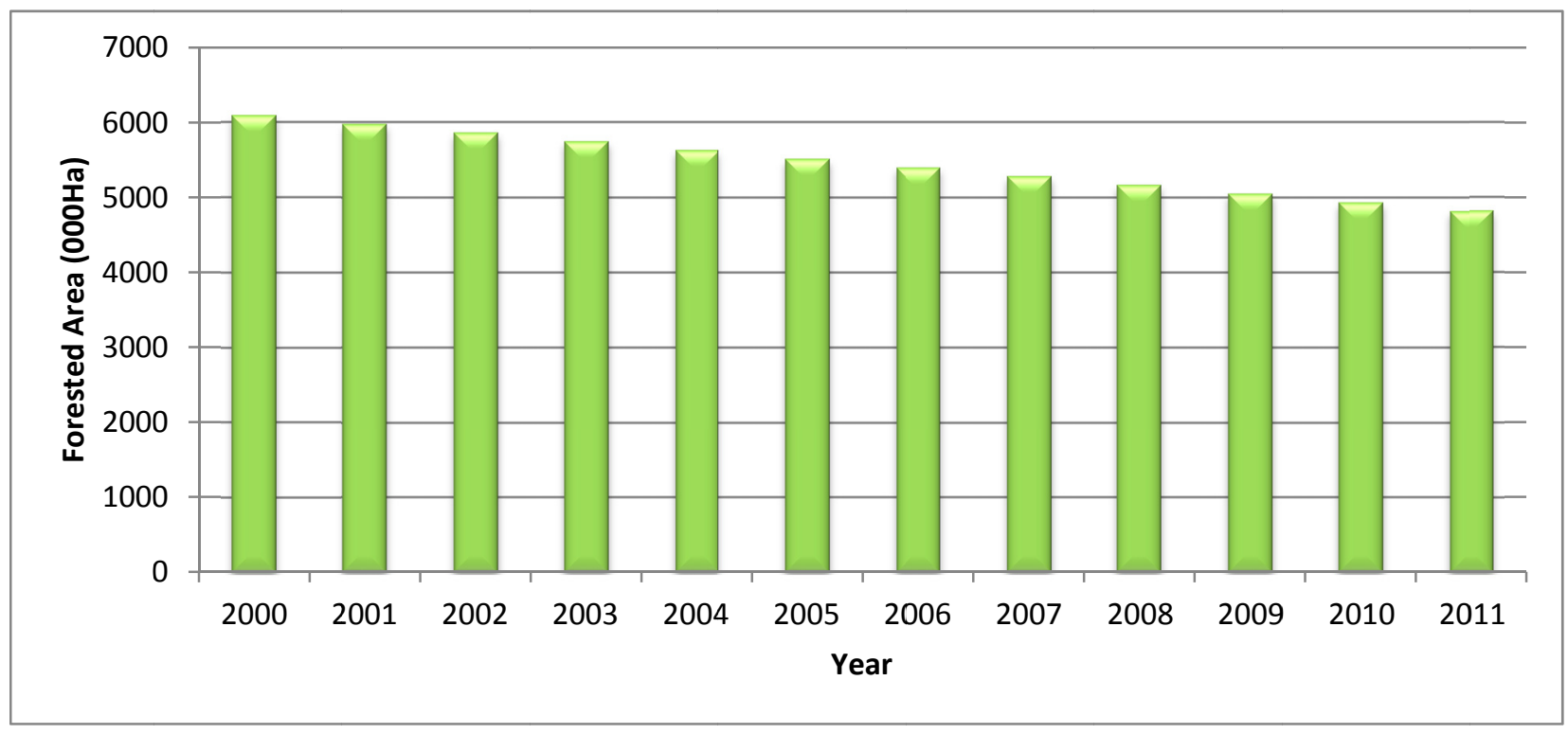

Figure 2. Trend in forested area left in Ghana from 2000 to 2011

Source: FAOSTAT, 2013

\section{Methodology}

\subsection{Theoretical Framework and Estimation of the Share of GDP Attributed to Environmental Capital Inputs}

Solow (1986) conceptualises environmental capital as a factor of production similar to human-made capital such as machinery and equipment. In this vein, the production of GDP is dependent on labour, human-made capital and environmental capital inputs. Following the Solow formulation, assuming a Cobb-Douglas function and constant returns to scale, an aggregate production function of the economy can be represented as follows in Equation 1:

$$
Y=A L^{\lambda} K^{\theta} E^{\delta}
$$

The equation expresses gross domestic product of a country $(\mathrm{Y})$ as a function of its total stock of labor (L), manufactured capital (K) environmental capital (E). Environmental capital denotes natural resources and endowments actually used for the production of national income such as proven oil and gas reserves, part of which is extracted for exports and also for local consumption. Thus it does not refer to all natural endowments of a country and therefore excludes natural endowments such as unproven oil and gas reserves. A is a measure of technological progress. The factor shares of national income accruing to labour (L), human-made capital (K) and environmental capital (E) are $\lambda, \theta$ and $\delta$ respectively. The factor shares, $\lambda$ and $\theta$ can be estimated using their respective marginal products assuming constant returns to scale. This estimation is based on the assumption that producers minimise costs with regards to decisions about use of inputs. This implies that the marginal product of manufactured capital equals the real rental price of capital and the marginal product of labour equals the real wage rate (Okabe, 2002).

The labour share of national income $\lambda$, is calculated as follows in Equation 2.

$$
\lambda=\left(\begin{array}{ll}
w & L
\end{array}\right) / Y
$$

where $\mathrm{w}$ represents the shadow wage rate and $\mathrm{L}$ is the skill-adjusted labour force.

The share of human-made capital of national income, $\theta$ is calculated as follows in Equation 3.

$$
\theta=\left(P_{K} K\right) / Y
$$

where $\mathrm{P}_{\mathrm{K}}$ is the shadow price of $\mathrm{K}$ and $\left[\left(\mathrm{P}_{\mathrm{K}} \mathrm{K}\right) / \mathrm{Y}\right]$ is the value of the marginal product of human-made capital or the human-made capital's share of national income based on the assumption of constant returns to scale.

The shadow price of human-made capital $\left(\mathrm{P}_{\mathrm{k}}\right)$, the real rental price of capital, is determined as the sum of the real interest rate of human-made capital (rint) and the depreciation rate of human-made capital ( $\rho$ ). Data on the depreciation rate of human-made capital $(\rho)$ for each year is sourced from World Bank (2013). The real interest rate is derived as long-term bond rate adjusted for by the inflation as denoted below in Equation 4.

$$
\text { rint }=((1+A) /(1+I))-1
$$

where $\mathrm{A}$ is the long-term government bond rate and $\mathrm{I}$ is the underlying inflation rate. 
By estimating the values of $\lambda$ and $\theta$, the environment capital factor share, $\delta$, can be determined simply as (1- $\lambda-\theta)$ due to the assumption of constant returns to scale. The size of the environmental capital stock (E) can then be estimated as follows in Equations 5a and 5b:

$$
\begin{aligned}
& \delta=\left(\begin{array}{ll}
E & P_{E}
\end{array}\right) / Y \\
& E=\left(\begin{array}{ll}
\delta & Y
\end{array}\right) / P_{E}
\end{aligned}
$$

where $\mathrm{P}_{\mathrm{E}}$ is the price of the environmental capital stock.

The estimation of the price of environmental capital $\left(\mathrm{P}_{\mathrm{E}}\right)$ is derived as follows in Equation 6:

$$
P_{E}=\text { rint }+E_{d}
$$

where rint is the real rental price of human-made capital and $\mathrm{E}_{\mathrm{d}}$ is the depreciation rate of environmental capital.

The estimate of the value of $\mathrm{P}_{\mathrm{E}}$ is based on the assumption that both natural capital and manufactured capital have the same real interest rate (rint) due to the fact that manufactured capital interest rate is the upper limit for the interest rate for environmental capital as used by Thampapillai and Hanf (2000). However, we use a different formulation for the assignment of depreciation of environmental capital from that used by Thampapillai and Hanf (2000). Thampapillai and Hanf argue that all rents owing to the entire stock of environmental capital should be set aside as a depreciation allowance for this capital.

\subsection{Theoretical Framework for Analysis of Environmentally-Sustainable National Income}

Following the theoretical framework where the environment is treated as factor of production, the sustainable national income is estimated using the expenditure approach. Consider the standard expenditure approach in GDP estimation which we outline below in Equation 7.

$$
G D P=C+I+G+X-M
$$

$\mathrm{C}$ is consumption expenditure, $\mathrm{I}$ is investment, $\mathrm{G}$ is government expenditure, $\mathrm{X}$ is export and $\mathrm{M}$ is import.

Economists allow for depreciation for human-made capital stock denoted as $\mathrm{D}_{\mathrm{hc}}$. Hence net domestic product (NDP) is the difference between GDP and $D_{\text {hc }}$ as shown in Equation 8 below.

$$
N D P=G D P-D_{h c}=(C+I+G+X-M)-D_{h c}
$$

Now we assume that investment, I is made up of two components, (1) human-made capital investments dealing with plant, machinery and equipment denoted as $\mathrm{I}_{\mathrm{hc}}$, and (2) environmental capital investments such as afforestation and restoration of rivers rendered unusable through mining activities denoted as $\mathrm{I}_{\mathrm{ec}}$. Currently in Ghana, the Ghana Statistical Service, the official national income statistics office, incorporates both types of investments as a single entity denoted here as I.

Equation 8 can be recast by delineating the two types of investments as follows in Equation 9.

$$
N D P=G D P-D_{h c}=\left(C+I_{h c}+I_{e c}+G+X-M\right)-D_{h c}
$$

We argue that a definition of environmentally-sustainable net domestic product or sustainable income (NDP s $_{\mathrm{s}}$ is shown in Equation 10 as $G D P-D_{h c^{-}} D_{e c}$.

$$
N D P_{s}=G D P-D_{h c^{-}} D_{e c}=\left(C+I_{h c}+I_{e c}+G+X-M\right)-D_{h c}-D_{e c}
$$

where the consumption of environmental capital stock is denoted as $\mathrm{D}_{\mathrm{ec}}$ and represents the replacement value of the total environmental capital stock used to produce national income.

While allowance for the depreciation of human-made capital $\left(\mathrm{D}_{\mathrm{hc}}\right)$ is a routine practice in the computation of annual GDP figures for government statistical agencies worldwide, the use of a depreciation allowance for the replacement of total environmental capital stock used in producing national income $\left(D_{e c}\right)$ is not a common feature of government statistical agencies. In Ghana, national income statisticians have used an average of 9.2\% of GDP for depreciation of human-made or manufactured capital for GDP accounting over the period from 1993 to 2012 with little variation in the annual figures based on a standard deviation of only $0.6 \%$. On the contrary, the estimated depreciation for different components of total environmental capital stock reported by the World Bank (2013) show highly variable figures from year to year (refer to Appendix 2 for figures on environmental depreciation allowances for Ghana). As described earlier, a purpose of this study is to estimate $\mathrm{D}_{\mathrm{ec}}$ and also to encourage its use by economists working on Ghanaian issues and the Ghana Statistical Service.

If $\mathrm{t}$ denotes time period $\mathrm{t}, \gamma_{1}$ and $\gamma_{2}(\mathrm{t})$ denote the proportions of GDP attributed to the depreciation allowances for human-made and environmental capital stocks respectively, then 


$$
N D P_{s}(t)=G D P(t)-\gamma_{1} G D P(t)-\gamma_{2}(t) G D P(t)
$$

Note that $\gamma_{1}$ is relatively constant from year to year and is treated as a constant for the remainder of this paper; however $\gamma_{2}(t)$ can vary greatly among years and is described with the t notation. The environmentally-adjusted value of national income can be deemed to be sustainable if there is no reduction in the stock of environmental capital and the value of environmental depreciation is less than new additions of environmental capital investments.

This is the weak sustainability criterion that human-made capital can be used to replace or to take the place of environmental capital through new investments that repair environmental capital assets (Hartwick, 1977; Hartwick, 1978; Solow, 1974; Solow, 1986; Solow, 1993). The alternative criterion of strong sustainability implies that some natural materials and environmental capital assets cannot be replaced. There are certain functions that environmental assets perform that cannot be replaced when these assets are destroyed, for example, the ozone layer (Commons and Stagl, 2005).

If we assume weak sustainability criterion, then we can analyse the environmentally-sustainable national income based on the concept that a steady state can be reached when all lost natural endowment can be restored through investments and positive returns net of depreciation are maintained. Environmentally-sustainable income therefore is the difference of a nation's economic return and the allowance made for the depreciation of environmental capital.

We expand our analysis by assuming that $\mathrm{C}$ and $\mathrm{I}$ are the only control variables while the remaining terms in Equation 7 are constant. We further expand on $\mathrm{C}$ and $\mathrm{I}$ and assume that $\mathrm{C}$ is directly related to $\mathrm{Y}$ (or GDP) as shown in Equation 12; and that $\mathrm{I}$ is related to real interest rate (rint) as indicated in Equations 13a, 13b and 13c.

$$
C=\alpha+\beta Y
$$

Where $\alpha$ is the autonomous consumption and $\beta$ is the marginal propensity to consume.

$$
\begin{gathered}
I=I_{h c}+I_{e c} \\
I_{h c}=F_{0}+F_{I} \text { rint } \\
I_{e c}=G_{0}+G_{1} \text { rint }
\end{gathered}
$$

Note that investments are made up of both investments in terms of additions to human-made plants and machinery, investments to increase the stock of total environmental capital and the levels of these investments are directly related to the real interest rate (rint), as suggested by macroeconomic theory (McConnell and Brue, 2002, p.166).

If we assume that $(\alpha+\mathrm{G}+\mathrm{X}-\mathrm{M})$ in Equation 6 is equal to a constant $\mathrm{H}$, then definitions for GDP can be denoted as shown in Equations 14, 15, 16 and 17.

$$
\begin{gathered}
G D P=H+(\beta Y)+\left(F_{0}+F_{l} \text { rint }\right)+\left(G_{0}+G_{l} \text { rint }\right) \\
\left.\left.G D P=H+F_{0}+G_{0}+(\beta Y)+F_{1} \text { rint }\right)+G_{l} \text { rint }\right) \\
G D P=J+(\beta Y)+\text { rint }\left(F 1+G_{l}\right) \\
G D P=J+\beta Y+L \text { rint }
\end{gathered}
$$

where $\mathrm{J}$ is a constant equal to $\mathrm{H}+\mathrm{F}_{0}+\mathrm{G}_{0}$ and $\mathrm{L}$ is a coefficient equal to $\mathrm{F} 1+\mathrm{G}_{1}$.

Environmentally sustainable income denoted as $\mathrm{NDP}_{\mathrm{s}}$ can be rewritten as follows in Equations 18, 19 and 20.

$$
\begin{gathered}
N D P_{s}(t)=(J+\beta Y(t)+\operatorname{Lrint}(t))-\gamma_{1}(J+\beta Y(t)+\operatorname{Lrint}(t))-\gamma_{2}(t)(J+\beta Y(t)+\operatorname{Lrint}(t)) \\
\gamma_{2}(t)=f\left(N D P_{s}, \operatorname{rint}\right) \\
\operatorname{Dec}(t)=f\left(N D P_{s}, \text { rint }\right)
\end{gathered}
$$

Equations 19 and 20 therefore suggest that the depreciation allowance for environmentally sustainable production $(\operatorname{Dec}(\mathrm{t}))$ is dependent on the real net national domestic product (NDP) and real interest rate (rint). These equations give us a guide to empirically test the relationship for Ghana.

3.3 Model Specification for Empirical Analysis of Factors Influencing the Level of Depreciation Required for Environmentally-Sustainable National Income

The model for the analysis of the factors influencing the level of depreciation required for environmentally sustainable national income is presented mathematically as follows:

$$
D E C(t)=f(R N D P s, R I N T)
$$


Where DEC is the real value of depreciation of environmental capital stock measured as million of Ghana cedis with 2006 as the base year;

RNDP is the real net domestic product of Ghana measured in million of Ghana cedis with 2006 as the base year;

RINT is the real interest rate of Ghana.

Equation 20 is recast in a log-linear form and shown in an econometric form in Equation 21.

$$
\text { ln } D E C(t)=\beta_{0}+\beta_{1} R N D P(t)+\beta_{2} R I N T(t)+U(t)
$$

where $\mathrm{t}$ is the year from 1993 to 2011 increasing from $(t=1, \ldots \ldots, 19)$ and $\mathrm{U}(\mathrm{t})$ is the stochastic error term initially assumed to have zero mean and constant variance.

A priori, it is expected that the coefficients $\boldsymbol{\beta}_{1}$ is expected to be positive reflecting an increase in depreciation of the environmental capital stock with an expanding economy. However, the sign of the coefficient related to $\boldsymbol{\beta}_{2}$ is expected to be negative. This is due to higher levels of investments and economic growth generated with lower levels of real interest rate by economic agents bringing about a negative relationship. Several variants of Equation 21 are empirically estimated. These include linear, log-log and lin-log versions (refer to Gujarati, 2003, pp.190-191 for a discussion of various empirical forms and the derivation of their slopes and elasticities).

\subsection{Data and Data Sources}

The value added and the expenditure approach figures for Ghana's GDP as well as inflation rate, and interest rate figures were obtained from Ghana Statistical Service (GSS) (2010a, 2010b, 2012, 2013a, 2013b) and the World Development Indicators (WDI) of the World Bank (2013). The real GDP figures used from 1993 to 2005 were obtained by back-casting two base years' economic series data - 1993 and 2006 - produced by GSS. A ratio of real GDP figures for the year 2006 that coincided with both the 1993 economic series and 2006 economic series (economic structures) was found by the division of the latter by the former to obtain a conversion ratio. The conversion ratio was then used to modify 1993 to 2005 economy real GDP figures (see Appendix 1) to estimate the back-cast figures that assumed a 2006 base year economy for the period, 1993 to 2005 (see Appendix 1). The real GDP figures from 2006 to 2012 used were the actual rebased data provided by GSS (2010a, 2012, 2013a, 2013b).

The total annual size of Ghana's labour force figures were obtained from census figures from 1984, 2000 and 2010 (Ghana Statistical Service, 2013c). Annual growth rate figures quoted in the censuses reports were used to forecast (using the interpolation method) the size of the labour size for all three types of labour - private informal, private formal and public. The value added to GDP by the agricultural sector was used to derive the wage per worker in the private informal labour force based on the size of the agricultural sector work force. This was based on the assumption that 90 percent of the work in the agricultural sector is in the private informal sector.

The total annual contributions received by the Social Security and National Investment Trust (SSNIT), the semi-autonomous worker pension fund, from private workers, were used to estimate the real private formal labour cost given that private formal sector employers are required by law to transfer specific employee and employer social security contributions to SSNIT on a monthly and annual basis. Government labour costs were obtained by using annual personnel emoluments as quoted in the Government of Ghana Budget statements with specific reference to wages and salaries and excluded transfer payments.

In order to obtain the environmental depletion over the years, adjusted savings for mineral, natural resources and net forest depletions as a percentage of gross national income (GNI) were summed up and used. These sets of data are available at the World Bank Data-base; World Development Indicators (WDI) of the World Bank (2013) and are reported in Appendix 2.

\section{Results}

\subsection{Results Dealing with the Share of GDP Attributed to Environmental Capital Inputs}

Table 2 provides the results of the aggregate environmental capital stock and inputs used in the production of of real GDP in Ghana from 1993 to 2012 based on constant 2006 economic conditions. The real value of human labour used over the 20-year period averaged about 7,783.93 million Ghana cedis (GHS). One Ghana cedi was worth about 0.45 United States dollar in mid-December 2013. The average real value of human-made capital inputs, such as machinery and equipment, used in the production of of real GDP however was lower at an average annual value of GHS3,726.61 million. The estimated real value of environmental capital inputs used to produce national income averaged about GHS5,460.95 million (Table 2) over the 20 year period. The size of total environmental capital stock 
averaged about GHS22,773.44 million which was larger than the average human-made capital stock (GHS17,457.99 million; refer to Table 2).

Table 3 reports the shares of GDP attributed to human labour, human-made capital inputs and environmental capital inputs over the 20-year period from 1993 to 2012. As mentioned earlier, this attribution analysis is anchored on the assumption of a constant returns to scale feature of the economy of Ghana (refer to Equation 1). The estimated average labour, human-made capital and environmental capital shares of GDP were $45 \%, 19 \%$ and $36 \%$ respectively over the 20-year period (see Table 3 and Figure 3). It is worthwhile to note that the more recent fast growth of the economy of Ghana over the last ten years has resulted in a relatively higher share for human-made capital inputs such as machinery and equipment compared to environmental capital inputs in the production of GDP. Further, labour share of GDP had remained relatively stable around the average of $45 \%$.

The relatively higher share for human-made capital over the more recent period is related to the emergence of the services sector as the most dominant of the three economic sectors of the economy since 2006. The other two sectors of the economy are agriculture and industry. The services sector led by the relatively rapid growth of the banking and financial intermediation, transport and storage, information and communication, and business, real estate and consultancy services, has contributed to large increases of human-made capital investment goods into the economy over the last decade as can be observed by the proliferation of bank branches throughout the country within a short period of time which has also boosted the growth of the construction industry.

The agricultural sector includes crops and livestock, cocoa, fishing and forestry sub-sectors. Government policy in recent times has focussed on the preservation of forest resources of the country and has led to reduced exports of timber and other forestry products. This is a factor for the relative decline of the share of environmental capital inputs in the production of real GDP in more recent times. The industrial sector of the economy is made up of construction, manufacturing, mining and quarrying, electricity, and water and sewerage sub-sectors. The construction sub-sector or industry has been one of the key drivers of economic growth of Ghana in the last decade (Anaman and Osei-Amponsah, 2007) and its development has involved large increases in the acquisition of locally-produced and imported machinery and equipment. This development is also a factor contributing to the increasing share of human-made capital (machinery and equipment) in the production of national income.

Table 2. Aggregate environmental capital stock and inputs used in the production of real GDP in Ghana from 1993 to 2012 (constant 2006 million Ghana cedis) except for price of labour $\left(\mathrm{P}_{\mathrm{L}}\right)$ which is quoted in constant 2006 Ghana cedis

\begin{tabular}{|c|c|c|c|c|c|c|c|c|c|c|}
\hline Year & RGDP & $\begin{array}{l}\text { Total } \\
\text { Labour } \\
\text { (L) } \\
\end{array}$ & $\mathbf{P}_{\mathbf{L}}$ & $\mathbf{L} * \mathbf{P}_{\mathbf{L}}$ & $\mathbf{P}_{\mathbf{K}}$ & $\begin{array}{l}\text { Total } \\
\text { Human-Made } \\
\text { Capital (K) } \\
\end{array}$ & $\left(\mathbf{K} * \mathbf{P}_{k}\right)$ & $\mathbf{P}_{\mathbf{E}}$ & $\begin{array}{l}\text { Total } \\
\text { Environmental } \\
\text { Capital (E) } \\
\end{array}$ & $\mathbf{E} * \mathbf{P}_{\mathbf{E}}$ \\
\hline 1993 & 10329.60 & 6655079 & 666.98 & 4287.80 & 0.13 & 4230.58 & 567.94 & 0.13 & 40774.69 & 5473.86 \\
\hline 1994 & 10667.31 & 6676163 & 654.55 & 4388.81 & 0.12 & 5409.42 & 648.22 & 0.12 & 46984.56 & 5630.27 \\
\hline 1995 & 11096.50 & 6801532 & 657.39 & 4557.66 & -0.06 & 6393.72 & -357.97 & -0.06 & -123183.38 & 6896.81 \\
\hline 1996 & 11606.51 & 6926900 & 670.09 & 4808.34 & 0.08 & 7294.50 & 580.76 & 0.08 & 78091.95 & 6217.41 \\
\hline 1997 & 12093.78 & 7052269 & 694.15 & 5080.41 & 0.21 & 8447.26 & 1797.40 & 0.21 & 24513.55 & 5215.97 \\
\hline 1998 & 12661.43 & 7177637 & 720.39 & 5431.98 & 0.28 & 9459.51 & 2645.03 & 0.28 & 16395.44 & 4584.42 \\
\hline 1999 & 13222.14 & 7303006 & 756.79 & 5739.26 & 0.29 & 10301.45 & 3019.05 & 0.29 & 15231.29 & 4463.83 \\
\hline 2000 & 13716.14 & 7428374 & 785.88 & 5936.37 & 0.20 & 11345.80 & 2262.54 & 0.20 & 27666.78 & 5517.23 \\
\hline 2001 & 14289.78 & 7722904 & 799.15 & 6288.14 & 0.17 & 12742.49 & 2120.46 & 0.17 & 35341.82 & 5881.18 \\
\hline 2002 & 14939.72 & 8017435 & 814.22 & 6685.39 & 0.28 & 13329.60 & 3710.98 & 0.28 & 16319.41 & 4543.35 \\
\hline 2003 & 15723.75 & 8311965 & 833.86 & 7195.22 & 0.13 & 14339.02 & 1898.45 & 0.13 & 50076.96 & 6630.08 \\
\hline 2004 & 16600.80 & 8606496 & 865.65 & 7569.51 & 0.18 & 15925.60 & 2930.95 & 0.18 & 33146.69 & 6100.33 \\
\hline 2005 & 17574.96 & 8901026 & 879.51 & 8336.29 & 0.18 & 17620.10 & 3246.08 & 0.18 & 32528.55 & 5992.60 \\
\hline 2006 & 18705.10 & 9195556 & 936.55 & 9092.59 & 0.21 & 19935.01 & 4199.43 & 0.21 & 25696.29 & 5413.08 \\
\hline 2007 & 19913.40 & 9490087 & 988.80 & 9260.60 & 0.22 & 22735.84 & 4958.59 & 0.22 & 26108.73 & 5694.21 \\
\hline 2008 & 21592.20 & 9784617 & 975.82 & 10076.07 & 0.19 & 26677.04 & 5146.70 & 0.19 & 33014.83 & 6369.43 \\
\hline 2009 & 22454.50 & 10079148 & 1029.79 & 11802.89 & 0.21 & 28919.96 & 6139.64 & 0.21 & 21253.05 & 4511.97 \\
\hline 2010 & 24251.90 & 10373678 & 1171.02 & 12084.99 & 0.24 & 32347.56 & 7895.97 & 0.24 & 17496.83 & 4270.94 \\
\hline 2011 & 27891.40 & 10668208 & 1164.97 & 13332.93 & 0.25 & 37623.64 & 9583.67 & 0.25 & 19530.12 & 4974.80 \\
\hline 2012 & 30098.90 & 10962739 & 1249.78 & 13723.26 & 0.26 & 44081.63 & 11538.35 & 0.26 & 18480.59 & 4837.29 \\
\hline Average & 16971.49 & 8401527 & 884.15 & 7783.93 & 0.19 & 17457.99 & 3726.61 & 0.19 & 22773.44 & 5460.95 \\
\hline
\end{tabular}




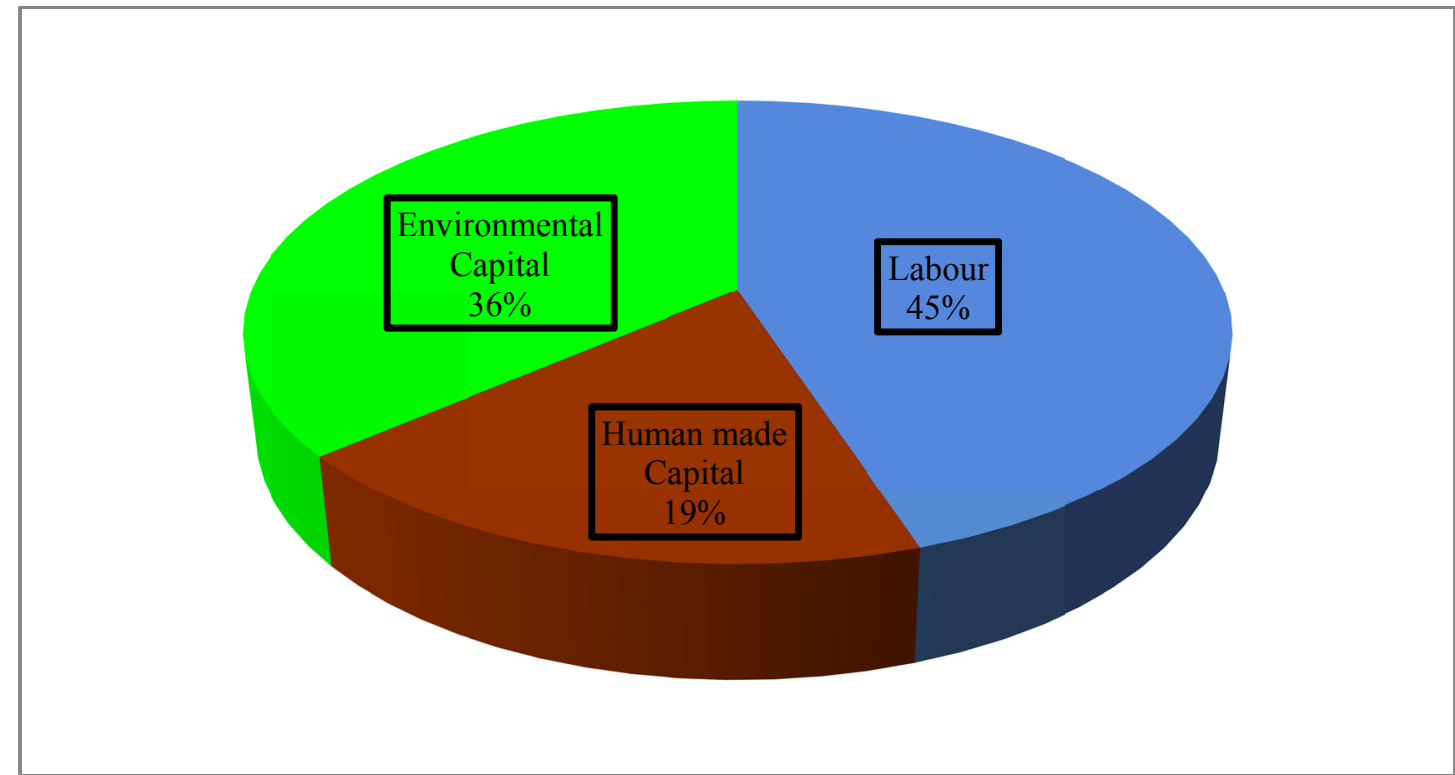

Figure 3. Average factor shares of labour, human-made capital and environmental capital inputs in the production of real GDP in Ghana, 1993 to 2012

Table 3. The shares of GDP attributed to labour, human-made capital, and environmental capital based on their uses as inputs for the production of real GDP, from 1993 to 2012

\begin{tabular}{cccc}
\hline Year & Share of Labour $(\boldsymbol{\lambda})$ & $\begin{array}{c}\text { Share of Human Made } \\
\text { Capital }(\boldsymbol{\theta})\end{array}$ & $\begin{array}{c}\text { Share of Environmental } \\
\text { Capital }(\boldsymbol{\delta})\end{array}$ \\
\hline 1993 & 0.42 & 0.05 & 0.53 \\
1994 & 0.41 & 0.06 & 0.53 \\
1995 & 0.41 & -0.03 & 0.62 \\
1996 & 0.41 & 0.05 & 0.54 \\
1997 & 0.42 & 0.15 & 0.43 \\
1998 & 0.43 & 0.21 & 0.36 \\
1999 & 0.43 & 0.23 & 0.34 \\
2000 & 0.43 & 0.16 & 0.40 \\
2001 & 0.44 & 0.15 & 0.41 \\
2002 & 0.45 & 0.25 & 0.30 \\
2003 & 0.46 & 0.12 & 0.42 \\
2004 & 0.46 & 0.18 & 0.37 \\
2005 & 0.47 & 0.18 & 0.34 \\
2006 & 0.49 & 0.22 & 0.29 \\
2007 & 0.47 & 0.25 & 0.29 \\
2008 & 0.47 & 0.24 & 0.29 \\
2009 & 0.53 & 0.27 & 0.20 \\
2010 & 0.50 & 0.33 & 0.18 \\
2011 & 0.48 & 0.34 & 0.18 \\
2012 & 0.46 & 0.38 & 0.16 \\
\hline Average & $\mathbf{0 . 4 5}$ & $\mathbf{0 . 1 9}$ & $\mathbf{0 . 3 6}$ \\
\hline
\end{tabular}

\subsection{Results Dealing with Factors Influencing the Level of Environmental Depreciation}

The results of the regression analysis dealing with factors influencing the levels of depreciation allowance for environmental capital are reported in Tables 4 and 5 respectively, for NDP and GDP, based on data from 1993 to 2011. For both models, their powers could be considered high with close to about $90 \% \mathrm{R}^{2}$ indicating that close to $90 \%$ of the variation in the environmental capital depreciation allowance was explained by the two independent variables. 
Both models were correctly specified based on the lack of significance of specification error using the Ramsey Reset test. The test of the normality of the error term indicated that there was the presence of a normal error term for both models making inferences based on Student $t$ and $F$ tests valid. This meant that the parameter estimates from the sample could be projected into the larger population. There was absence of significant heteroscedasticity and autocorrelation based on the reported Langrange Multiplier (LM) tests.

However, given the superior power of the model using NDP as the independent variable reported in Table 4, this model was used for further discussion as suggested by the earlier theoretical framework developed in this paper. The relationship between depreciation allowance (DEC) for environmental capital and national income was clearly established from the study over the 20-year period. It is important to note that the use of NDP, which accounts for the depreciation of human-made capital stock in the production of GDP, gives better results than using just GDP.

Table 4. Results of estimated regression equation for depreciation allowance (Dec) for environmental capital for Ghana from 1993 to 2011 with real national domestic product (NDP) as an independent variable

Dependent Variable is LDec (natural logarithm of Dec)

\begin{tabular}{llccc}
\hline & Explanatory Variable & Parameter Estimate & T-Statistic & P Value \\
\cline { 2 - 5 } & INTERCEPT & 5.685 & 32.950 & $0.000^{*}$ \\
\cline { 2 - 5 } & RNDP & 0.000121 & 11.335 & $0.000^{*}$ \\
\cline { 2 - 5 } $\mathrm{R}^{2}$ & -1.019 & -1.704 & 0.108 \\
\cline { 2 - 5 } Adjusted $\mathrm{R}^{2}$ & $0.895^{*}$ & & \\
& $0.882^{*}$ & &
\end{tabular}

Probability level of significance of model specification based on the Ramsey Reset test for correct model specification 0.559

Probability level of significance level for autocorrelation based on the Langrange Multiplier (LM) test for no significant autocorrelation $\quad 0.110$

Probability level of significance for heteroscedasticity based on the LM test for no significant heteroscedasticity 0.458

Probability level of significance of the normality of the error term based on the Jarque-Bera test of normality of the error term 0.634

Note: * denotes that parameter is statistically different from zero at $5 \%$ level.

Table 5. Results of estimated regression equation for depreciation allowance (DEC) for environmental capital for Ghana from 1993 to 2011 with real GDP as an independent variable

Dependent Variable is LDEC (natural logarithm of DEC)

\begin{tabular}{llccc}
\hline & Explanatory Variable & Parameter Estimate & T-Statistic & P Value \\
\cline { 2 - 5 } & INTERCEPT & 5.715 & 32.640 & $0.000^{*}$ \\
\cline { 2 - 5 } & RGDP & 0.000107 & 11.048 & $0.000^{*}$ \\
\cline { 2 - 5 } $\mathrm{R}^{2}$ & -1.000 & -1.635 & 0.122 \\
\cline { 2 - 5 } Adjusted $\mathrm{R}^{2}$ & $0.890^{*}$ & & \\
& $0.877^{*}$ & &
\end{tabular}

Probability level of significance of model specification based on the Ramsey Reset test for correct model specification 0.500

Probability level of significance level for autocorrelation based on the Langrange Multiplier (LM) test for no significant autocorrelation 0.100

Probability level of significance for heteroscedasticity based on the LM test for no significant heteroscedasticity 0.533

Probability level of significance of the normality of the error term based on theJarque-Bera test of normality of the error term 0.640

Note: * denotes that parameter is statistically different from zero at $5 \%$ level. 


\section{Conclusion and Recommendation}

We analysed the contributions of human labour, human-made capital inputs such as machinery and equipment, and environmental capital inputs such as natural resources, minerals and proven oil reserves, in the production of GDP in Ghana over the 20-year period from 1993 to 2012. The analysis was based on the assumption that the aggregate economy as a whole exhibited a constant returns to scale feature. The results indicated that the average annual share of attributed to labour in the production of GDP was about $45 \%$. Human-made capital inputs contributed about $19 \%$ of GDP. The remaining share of $36 \%$ was the estimated value of environmental capital inputs used to produce GDP. We also established that environmental depreciation was significantly related to both real GDP and real NDP in a positive log-linear fashion while its relationship to real interest rate was negative but not statistically significant.

The relatively high value of environmental inputs used to produce real GDP suggests an important policy role of conservation and maintenance of environmental capital and resources in the country especially in the light of rapid depletion of some natural resources. One way of improving the environmental capital stock is for purposively-created environmental investments through the creation of new national parks and the improved maintenance of old national parks and reservation areas. This will expand ecotourism services and lead to more sustainable and equitable form of economic growth.

Further, given that Ghana is ranked lowly internationally in environmental sanitation rankings, we also contend that more public monies be set aside to improve the quality of environmental sanitation in the country as this will improve both the quality of labour (enhanced human capital) through the reduction of sanitation-related diseases which account for about $70 \%$ of outpatient cases at hospital and clinics in the country. This will also improve the quality and preservation of the natural environment making it easier for people to work under more hospitable conditions thus contributing to more equitable and shared growth.

Another policy implication arising from this study relates to the management of Ghana's newly-found oil reserves. Ghana started exporting in significant commercial quantities in 2011 when its economy grew by $15.0 \%$ during that year based on the growth of real GDP. The concern for prudently using the money created by oil production led the Parliament of Ghana to enact a law regulating the use of the money called the Petroleum Revenue Management Act of 2010. This Act created two sovereign funds namely (1) Ghana Stabilisation Fund and (2) Ghana Heritage Fund. The purpose of the Ghana Stabilisation Fund is to smoothen government budget imbalances due global oil price volatility. The aim of the Ghana Heritage Fund is aimed at providing income for future generations when oil reserves would have been fully depleted. Seventy percent of the proceeds of the current oil revenues of the Government of Ghana are put into the Ghana Stabilisation Fund with the remaining 30 percent set aside for the Ghana Heritage Fund which are part of the country's foreign exchange reserves maintained by the Central Bank, Bank of Ghana.

Based on the results produced by this paper, we suggest that part of the Ghana Heritage Fund be set aside to create a Ghana Environmental Fund that can be used to repair and maintain the environmental and natural assets which are depleted and destroyed by the fast economic growth for use by future generations. It is largely pointless to leave money to the future generations without some basic minimum level of environmental capital stock that can allow sustainable production of goods and services desired by the future generations.

We suggest that the Ghana Environmental Fund could be one-third the size of the Ghana Heritage Fund given that on average GDP requires the value of environmental capital inputs equivalent to about one-third of GDP. The Environmental Fund can be used to rehabilitate the numerous rivers, lagoons and lakes which have been partially destroyed by human activities through mining and the dumping of solid wastes by the general public. It is important to leave future generations not just physical monies that they can use to purchase goods and services but it is crucial to leave them with good quality natural environments that can allow the production of goods and services for their use.

Finally, we recommend that the procedures and objectives of our study are used by the Ghana Statistical Service to compute additional national income statistics that emphasise environmental accounting procedures and account effectively for environmental degradation. The estimation of environmental capital inputs used in the production of GDP based on our study and its extensions to include more advanced tools can help to provide more information for policymakers and contribute to the debate concerning the need to establish specific Environment Capital Funds purposely set aside for environmental investments and maintenance.

\section{Acknowledgments}

We gratefully acknowledge the financial assistance of the Office of Research, Innovation and Development, University of Ghana, Legon, Accra, Ghana for financing this study over the 17-month period from August 2012 to December 2013.We also thank officials of the Office of National Income Accounts, Ghana Statistical Service for 
their assistance with the provision of relevant data for the study and for their review of the back casting GDP figures that we developed for this study over the period, 1993 to 2005.

\section{References}

Anaman, K. A. (2006). Determinants of Economic Growth in Ghana. Accra: The Institute of Economic Affairs.

Anaman, K. A., \& Osei-Amponsah C. (2007). Analysis of the Causality Links between the Growth of the Construction Industry and the Growth of the Macro-economy in Ghana, Construction Management and Economics, 25(9), 951-961. http://dx.doi.org/10.1080/01446190701411208

Armstrong, H., \& Read, R. (2004). The Economic Performance of Small States and Islands: The Importance of Geography. Paper Presented at Islands of the World VIII International Conference, Taipei, Taiwan.

Bartelmus, P., Lutz, E., \& Schweinfest, S. (1992). Integrated Environmental and Economic Accounting - A Case Study for Papua New Guinea. Paper Presented at the Workshop on Environmental Economics and Natural Resource Management in Developing Countries, Washington, D.C.: World Bank.

Benneh, G., Agyepong, G. T., \& Allotey, J. A. (1990). Land Degradation in Ghana. London: Commonwealth Secretariat.

Bloom, D., \& Sachs J. (1998). Geography, Demography and Economic Growth in Africa. Brookings Papers on Economic Activity, 2, 207-295. http://dx.doi.org/10.2307/2534695

Brundtland Commission. (1987). Food 2000: Global Polices for Sustainable Agriculture. London: Zed Books.

Commons, M., \& Stagl, S. (2005). Ecological Economics: An Introduction. Cambridge: Cambridge University Press. http://dx.doi.org/10.1017/CBO9780511805547

Dickson, K. B., \& Benneh, G. (1988). A New Geography of Ghana. London: Longman.

Environmental Protection Agency (EPA). (2011). Ghana's Second National Communication to the United Nations Framework Convention on Climate Change (UNFCCC). Accra: EPA.

Environmental Protection Agency (EPA). (2012). Capacity Building for the Assessment and Monitoring of the Cost of Environmental Degradation in Ghana-Phase I. London: The IDL Group.

Euronet Consulting. (2012). Country Environmental Profile: Republic of Ghana. Accra: Ministry of Finance and Economic Planning and the European Commission.

Food and Agriculture Organization Statistics Division (FAOSTAT). (2013), Land Use Database 2013. Rome: FAO. Retrieved 16 October, 2013, from http://faostat.fao.org/site/377/DesktopDefault.aspx?PageID=377

Ghana Statistical Service (GSS). (2010a). Gross Domestic Product Figures, 1993-2009 Based on the 1993 Series. Accra: GSS.

Ghana Statistical Service (GSS). (2010b). Rebased Gross Domestic Product Figures, 2006-2010. Accra: GSS.

Ghana Statistical Service (GSS). (2012). Revised Gross Domestic Product, 2011. Accra: GSS.

Ghana Statistical Service (GSS). (2013a). Revised Gross Domestic Product, 2012. Accra: GSS.

Ghana Statistical Service (GSS). (2013b). Gross Domestic Product Expenditure Approach New Series. Accra: GSS.

Ghana Statistical Service (GSS). (2013c). 2010 Population and Housing Census National Analytical Report. Accra: Ghana Statistical Service.

Hamilton K., \& Lutz E. (1996). Green National Accounts: Policy Uses and Empirical Experience. Environment Department Papers, Environmental Economic Series, No.039, Washington D.C.: World Bank.

Hartwick, J. M. (1977). Intergenerational Equity and the Investing of Rents from Exhaustible Resources. The American Economic Review, 67(5), 972-974.

Hartwick, J.M. (1978a). Investing Returns from Depleting Renewable Resource Stocks and Intergenerational Equity. Economic Letters, 1(1), 85-88. http://dx.doi.org/10.1016/0165-1765(78)90102-7

Hartwick, J.M. (1978b). Substitution among Exhaustible Resources and Intergenerational Equity. The Review of Economic Studies, 45(2), 347-354. http://dx.doi.org/10.2307/2297349

Hicks, J. (1946). Value and Capital ( $2^{\text {nd }}$ ed.). Oxford: Oxford University Press. 
Hotelling, H. (1931). The Economics of Exhaustible Resources. Journal of Political Economy, 39(2), 137-175. http://dx.doi.org/10.1086/254195

Lindhal, E. (1933). The Concept of Income. In Bagge, G. (Ed.), Economic Essays in Honour of Gustav Cassel (p.720). London: George Allen and Unwin.

Masters, W., \& McMillan M. (2001). Climate and Scale in Economic Growth. Journal of Economic Growth, 6, 167-186. http://dx.doi.org/10.1023/A:1011398431524

McConnell, C.R., \& Brue, S.L. (2002). Economics: Principles, Problems, and Policies. McGraw-Hill Irwin, Singapore.

Ministry of Land and Natural Resources (MLNR). (2012). Ghana Forest Investment Programme. Accra: MLNR, p.119.

Mohammed, S. J., \& K. A. Anaman. (2003). Analysis of the Health and Environmental Quality Adjusted Gross Domestic Product in Brunei Darussalam. In Applied Economic Analysis in Brunei Darussalam: Evaluation of Economic Growth and Trade, Microeconomic Efficiency and Analysis of Socio-economic Problems (pp. 47-66). Bandar Seri Begawan: Universiti Brunei Darussalam.

Okabe M. (2002). International R\&D Spillovers and Trade Expansion: Evidence from East Asian Economies. Asean Economic Bulletin, 19(2), 141-154. http://dx.doi.org/10.1355/AE19-2B

Pearce, D., \& Barbier E.B. (2000). Blueprint for a Sustainable Economy. London: Earthscan, p.273.

Solorzano, R., de Camino, R., Woodward, R., Tosi, J., Watson, V., Vasquez, A., ... Cruz, W. (1991). Accounts Overdue: Natural Resource Depreciation in Costa Rica. Washington, D.C.: World Resources Institute.

Solow, R.M. (1974). Inter-generational Equity and Exhaustible Resources. Review of Economic Studies: Symposium of the Economics of Exhaustible Resources, 41, 29-45. http://dx.doi.org/10.2307/2296370

Solow, R.M. (1986). On the Intergenerational Allocation of Natural Resources. Scandinavian Journal of Economics, 88(1), 141-149. http://dx.doi.org/10.2307/3440280

Solow, R.M. (1993). Sustainability: An Economist's Perspective. In Dorfman, R. and Dorfman, N. (Eds.), Economics of the Environment. New York: Norton.

Solow, R.M. (1993). An Almost Practical Step towards Sustainability. Resources Policy, 16, 162-172. http://dx.doi.org/10.1016/0301-4207(93)90001-4

Thampapillai, D. (2002). Environmental Economics: Concepts, Methods and Policies. New York: Oxford University Press, p.222.

Thampapillai, D.J., \& Hanf, C-H. (2000). The Internalisation of Environmental Capital Stocks into an Aggregate Cobb-Douglas Function. Economic Analysis and Policy, 30(2), 209-215.

Thampapillai, D.J., \& Uhlin, H. (1997). Environmental Capital and Sustainable Income: Basic Income and Empirical Tests. Cambridge Journal of Economics, 21(3), 379-394. http://dx.doi.org/10.1093/oxfordjournals.cje.a013676

United Nations (UN). (1968). A System of National Income Accounts. New York: UN.

United Nations (UN). (1993). Integrated Environmental and Economic Accounting. New York: UN.

United Nations (UN). (2000). Handbook of National Accounting Integrated Environmental and Economic Accounting: An Operational Manual. New York: UN.

Water Resource Commission (WRC). (2011). Annual Report, Issue 13. Accra: WRC.

World Bank. (2012). Environment - Natural Capital Accounting. Washington, D.C.: World Bank. Retrieved 16 July 2014 ,

http://www.worldbank.org/en/topic/environment/brief/environmental-economics-natural-capital-accounting

World Bank. (2013). 2012 World Development Indicator (WDI). Washington D.C.: World Bank. 
Appendix 1. GDP back-casting results based on the 1993 and 2006 GDP series data used to derive consistent GDP data based on 2006 economic structure, 1993 to 2012

\begin{tabular}{rrrrc}
\hline Year & $\begin{array}{c}\text { GSS ngdp 1993 } \\
\text { economic structure } \\
\text { series which were last } \\
\text { produced in June 2010 }\end{array}$ & $\begin{array}{c}\text { ngdp 2006 economic } \\
\text { structure series } \\
\text { produced using the } \\
\text { method of backcasting }\end{array}$ & $\begin{array}{c}\text { GSS rgdp 1993 } \\
\text { economic structure } \\
\text { series which were last } \\
\text { produced in June 2010 }\end{array}$ & $\begin{array}{c}\text { rgdp 2006 economic } \\
\text { structure series } \\
\text { produced using the } \\
\text { method of backcasting }\end{array}$ \\
\hline 1993 & 387.25 & 620.6 & 387.250 & 10329.6 \\
1994 & 520.52 & 834.2 & 399.910 & 10667.3 \\
1995 & 775.26 & 1242.4 & 416.000 & 11096.5 \\
1996 & 1133.92 & 1817.2 & 435.120 & 11606.5 \\
1997 & 1411.34 & 2261.7 & 453.387 & 12093.8 \\
1998 & 1729.571 & 2771.7 & 474.668 & 12661.4 \\
1999 & 2057.979 & 3298.0 & 495.689 & 13222.1 \\
2000 & 2715.27 & 4351.4 & 514.209 & 13716.1 \\
2001 & 3807.074 & 6101.0 & 535.714 & 14289.8 \\
2002 & 4886.241 & 7830.5 & 560.080 & 14939.7 \\
2003 & 6615.77 & 10602.1 & 589.473 & 15723.7 \\
2004 & 7988.739 & 12802.4 & 622.352 & 16600.8 \\
2005 & 9726.06 & 15586.5 & 658.873 & 17575.0 \\
$\mathbf{2 0 0 6}$ & $\mathbf{1 1 6 7 1 . 9 9}$ & $\mathbf{7 0 1 . 2 3 8}$ & $\mathbf{1 8 7 0 5 . 0 ^ { * }}$ \\
2007 & & $23154.0^{*}$ & & $19913.0^{*}$ \\
2008 & & $31235.0^{*}$ & & $21592.0^{*}$ \\
2009 & & $38023.0^{*}$ & & $22454.0^{*}$ \\
2010 & & $46042.0^{*}$ & & $24252.0^{*}$ \\
2011 & $59816.0^{*}$ & & $27891.0^{*}$ \\
2012 & & $73109.0^{*}$ & $30099.0^{*}$ \\
\hline
\end{tabular}

Sources: Derived from the 1993 and 2006 GDP Series Data Released by the Ghana Statistical Service on 30 June 2010 and 9 April 2013 respectively.

Notes: ngdp denotes nominal gross domestic product while rgdp denotes real gross domestic product.

The figures denoted in asterisk are rebased figures based on the 2006 structure of the economy released by Ghana Statistical Service from 2010 to 2013. 
Appendix 2. Figures for environmental depreciation as proportion of gross national income from the World Development Indicator (WDI) report

\begin{tabular}{ccccc}
\hline Year & Mining CEM & Forestry CEM & $\begin{array}{c}\text { Natural resource } \\
\text { CEM }\end{array}$ & $\begin{array}{c}\text { Total Economy } \\
\text { (M2) (CEM) }\end{array}$ \\
\hline 1993 & 0.0068 & 0.0301 & 0.0369 & 0.0738 \\
1994 & 0.0128 & 0.0391 & 0.0519 & 0.1038 \\
1995 & 0.0069 & 0.0319 & 0.0388 & 0.0776 \\
1996 & 0.0085 & 0.0287 & 0.0372 & 0.0744 \\
1997 & 0.0029 & 0.0284 & 0.0314 & 0.0627 \\
1998 & 0.0003 & 0.0264 & 0.0267 & 0.0534 \\
1999 & 0.0003 & 0.0268 & 0.0272 & 0.0542 \\
2000 & 0.0007 & 0.0426 & 0.0436 & 0.0868 \\
2001 & 0.0009 & 0.0435 & 0.0444 & 0.0888 \\
2002 & 0.0099 & 0.0377 & 0.0477 & 0.0953 \\
2003 & 0.0151 & 0.0341 & 0.0494 & 0.0985 \\
2004 & 0.0157 & 0.0319 & 0.0482 & 0.0958 \\
2005 & 0.0175 & 0.0313 & 0.0487 & 0.0975 \\
2006 & 0.0215 & 0.0176 & 0.0391 & 0.0782 \\
2007 & 0.0227 & 0.0163 & 0.0391 & 0.0781 \\
2008 & 0.0271 & 0.0160 & 0.0431 & 0.0862 \\
2009 & 0.0446 & 0.0168 & 0.0614 & 0.1227 \\
2010 & 0.0511 & 0.0143 & 0.0671 & 0.1325 \\
2011 & 0.0709 & 0.0131 & 0.1050 & 0.1891 \\
2012 & - & - & - & - \\
\hline
\end{tabular}

Source: World Development Indicators of the World Bank Released in 2013. 